\title{
ЕКЗОГЕННІ ФАКТОРИ ВПЛИВУ НА СТРАТЕГІЧНІ ОРІЄНТИРИ РОЗВИТКУ ВІТЧИЗНЯНИХ ПІДПРИЕМСТВ
}

\section{ЭКЗОГЕННЫЕ ФАКТОРЫ ВЛИЯНИЯ НА СТРАТЕГИЧЕСКИЕ ОРИЕНТИРЫ РАЗВИТИЯ ОТЕЧЕСТВЕННЫХ ПРЕДПРИЯТИЙ}

\section{EXOGENOUS FACTORS INFLUENCING STRATEGIC GUIDELINES FOR THE DEVELOPMENT OF DOMESTIC ENTERPRISES}

В межах статті проведено аналіз екзогенних факторів впливу на імперативи розвитку вітчизняних промислових підприємства в умовах розповсюдження прочесів глобалізачії. Виділено три основних групи чинників, щуо впливають на стратегію розвитку вітчизняного товаровиробника, а саме: розвиток сучасної інноваційної економіки, щзо базується на знаннях; посилення інформаційного впливу на виробниитво; кластерномережевий характер організації та управління виробництвом. На основі аналізу означених факторів, визначена необхідність пошуку нових методів адаптації, щзо відбуваються під впливом двох основних факторів: фактору часу та фактору розширення простору. Підкреслено, щзо підвищення оперативності дій (фактор часу) потребує нового підходу щодо пошуку нових методів управління виробництвом, а бажання отримання в високих позииій у певній галузі на всіх типах ринків вимагає від товаровиробників розширення ринків збуту (фактор розширення простору). Зазначено, щчо поштовхом для активізації діяльності підприємства на світовому ринку має стати кластерномережевий принщип організації підприємств, який відображає зв'язок між елементами внутрішнього та зовнішнього середовища підприємства.

Ключові слова: екзогенні фактори, стратегія, імперативи розвитку, інноваційна економіка, інформаційний вплив, кластерно-мережевий характер організації.

В рамках статьи проведен анализ экзогенных факторов влияния на императивы развития отечественных промылленных предприятиях в условиях распространения процессов глобализачии. Выделено три основных группы факторов, влияющих на стратегию развития отечественного товаропроизводителя, а именно: развитие современной инновационной экономики, основанной на знаниях; усиление информационного воздействия на производство; кластерно-сетевой характер организации и управления производством. На основе анализа указанных факторов, определена необходимость поиска новых методов адаптации, которые происходят под влиянием двух основных факторов: фактора времени и фактора расширения пространства. Подчеркнуто, что повышение оперативности действий (фактор времени) требует нового подхода к поиску новых методов управления производством, а желание получения высоких позиций в определенной отрасли на всех типах рынков требует от товаропроизводителей расширение рынков сбыта (фактор расширения пространства). Указано, что толчком для активизации деятельности предприятия на мировом рынке должно стать кластерносетевой принции организации предприятий, который отражает связь между элементами внутренней и внешней среды предприятия. 
Ключевые слова: экзогенные факторы, стратегия, императивы развития, инновационная экономика, информационное воздействие, кластерно-сетевой характер организации.

In article the analysis of exogenous factors influencing the development imperatives of domestic industrial enterprises in the conditions of globalization. Three main groups of factors influencing the development strategy of domestic producers, namely: the development of modern innovative economy based on knowledge; strengthening information impact on production; cluster-network nature of the organization and production management. Based on the analysis of these factors, identified a need for new methods of adaptation that occur under the influence of two main factors: the time factor and the expansion of space. Emphasized that improving the efficiency of actions (time factor) requires a new approach to the search for new methods of production management, and the desire to get high rankings in a particular industry in all types of markets requires producers expanding markets (factor expansion of space). Indicates that the impetus for the revitalization of the enterprises on the world market should be cluster-network principle of organization of enterprises, which represents the relationship between the elements of internal and external environment of the enterprise.

Key words: exogenous factors, strategy, development imperatives, innovative economy, informational influence, cluster-network nature of the organization

Вступ. Сьогоднішні тенденції позиціонування підприємств на всіх типах ринків пов'язані з розповсюдженням нових знань, які є основою для розвитку інформаційних та комунікаційних технологій, технологічних та нетехнологічних новацій тощо.

3 одного боку, перетворення знань у конкурентні переваги позитивно впливає на збільшення продуктивності праці та прибутків підприємств. А 3 іншого, надає можливості для впровадження інновацій, що підвищують конкурентоспроможність продукції та сприяють становленню лідерських позицій вітчизняних товаровиробників на всіх типах ринків. Іншими словами, одним 3 домінантних чинників формування стратегічних орієнтирів вітчизняних підприємств стає прискорений розвиток економіки, основою якої стають знання.

Підкреслимо, що у науковій літературі не існує єдиної думки щодо визначення сучасної економіки. Сьогодні можна виділити декілька підходів щодо ознаки даного феномену в залежності від того, які властивості економічних систем, їх підсистем та окремих елементів розглядається найбільш глибоко.

В економічному просторі широкого опанування набули концепції постіндустріального суспільства (Д. Белл, Е. Гідденс, В. Іноземцев, А. Турен, Е. Тоффлер), інформаційної економіки (Ф. Махлуп, М. Порат, , Т. Стоуньєр,), мережевої економіки (М. Кастельс, К. Келлі), інноваційної економіки (Й. Шумпетер), неоекономіки (О Бузгалін, У. Демінг, А. Колганов), економіки знань (П. Друкер, Г. Клейнер, В. Макаров) [1, 2, 4, 5, 7], кожна 3 яких 
акцентує увагу на певному факторі впливу на стратегічні орієнтири будьякого економічного агента в умовах конкуренції та глобалізації ринків. Однак у наявних наукових роботах і дослідженнях недостатньо приділено увагу комплексному аналізу зовнішніх факторів впливу на імперативи розвитку вітчизняних товаровиробників, серед яких ключовими виступають: розвиток сучасної інноваційної економіки, що базується на знаннях; посилення інформаційного впливу на виробництво; кластерно-мережевий характер організації та управління виробництвом.

Постановка завдання. Метою статті $\epsilon$ комплексний аналіз екзогенних факторів впливу на стратегічні орієнтири розвитку вітчизняних підприємств в умовах глобалізації ринків. Задля чого розглянемо три основних групи чинників, що впливають на стратегію розвитку вітчизняного товаровиробника, а саме: розвиток сучасної інноваційної економіки, що базується на знаннях; посилення інформаційного впливу на виробництво; кластерно-мережевий характер організації та управління виробництвом.

Методологія. В основу дослідження покладено системний підхід та загальнонаукові методи наукового пізнання процесів формування стратегії розвитку вітчизняних промислових підприємства в умовах розповсюдження глобалізації.

Результати дослідження. Сьогодні існує декілька підходів щодо визначення сучасної економіки. Так, концепція постіндустріального суспільства визначає послідовність етапів соціально-економічного розвитку, за рахунок зміни яких відбувається нарощування обсягів конкурентоспроможної промислової продукції. Згідно з означеною теорією, економіка проходить три послідовних стадії розквіту економіки, кожна з яких висуває певні вимоги щодо стратегії розвитку національних товаровиробників [1]:

1) Сировинна економіка, що грунтується не на застосуванні інтелектуального потенціалу підприємства, а на природній ренті, що отримується внаслідок експорту природних ресурсів (сировини). Основною ознакою такої економіки $\epsilon$ низький рівень розвитку людського капіталу, який передбачає науково-технічну відсталість підприємств та їх залежність у системі світового господарства [1]. За умов розвитку сировинної економіки, лідерами ринку стають підприємства добувної галузі. Зазначимо, що з позиції зовнішньоекономічної стратифікаційної системи, означеним підприємствам притаманна вертикальна підпорядкованість лідерам обробної промисловості у світовому розподілі праці.

2) Індустріальна економіка, що базується на підвищенні продуктивності праці за рахунок збільшення капіталовкладень у засоби виробництва реального сектору економіки. Основою всіх відносин (як виробничих, так і невиробничих) стає приватна власність на капітал, яка 
визначається К.Марксом як «само-зростаюча вартість» [2, с 588], що передбачає наявність високо розвинутої фінансово-кредитної і грошової систем; панування машинного виробництва на основі механізації та реорганізації виробництва; розвиток людського капіталу. Джерелом лідерства підприємств на ринку починає виступати збільшення обсягів виробництва за рахунок економії матеріальних витрат. Домінуючими критеріями становлення лідерства підприємств на ринку стає застосування трьох соціальноекономічних законів - закону підвищення потреб; зміни праці та комерціалізація закону економії часу виробництва. Причинами вживання яких стають:

- механізація виробництва (перехід від ручної праці до машинного виробництва);

- підвищення ролі людського капіталу, як інтенсивного фактору розвитку підприємства;

- трансформація інститутів освіти та перетворення науки в продуктивну силу;

- зміни економічних та організаційно-технологічних умов господарювання;

- поява підприємців, здатних до ризику шляхом застосування накопичених знань;

- збільшення обсягів інтелектуальної продукції, що сприяють переходу від одного технологічного укладу до іншого;

- розвиток освіти, науки та підприємницьких здібностей, які стають основою для впровадження інновацій на підприємствах.

У сукупності, означені чинники надають можливості для підвищення продуктивності праці та сприяють формуванню високопрофесійного людського капіталу підприємства. Іншими словами, розвиток корпоративного людського капіталу стає домінантним критерієм формування генеральної стратегії розвитку підприємства на ринку.

3) Постіндустріальна економіка, що характеризується наявністю творчого креативно-налаштованого економічного прошарку - економічної еліти, яка забезпечує виробництво інформацією, науковими знаннями та наукомісткими технологіями. Внаслідок структурної перебудови ринку, відбувається розвиток тих галузей промисловості, що користуються великим попитом на всіх типах ринків; відбувається санація недієздатних економічних агентів та створюються умови для розвитку наукоємних високотехнологічних підприємств.

За умов становлення постіндустріальної економіки, технічним базисом для формування стратегічних орієнтирів розвитку підприємства стає широке застосування інформаційно-комунікаційних технологій (IКT) та автоматизованих систем управління (АСУ). В якості джерела технологічних 
та нетехнологічних інновацій починають виступати накопичені знання, а домінуючою власністю стає не стільки приватна, скільки корпоративна та інституціональна власність на засоби виробництва. Значно скорочується i часовий проміжок життєвого виробничого циклу оновлення продукції: 3 моменту появи творчої креативної ідеї до іiі практичного застосування i впровадження у виробництво. 3 метою організації інноваційної діяльності, на підприємствах створюються науково-дослідні відділи; відбувається зміна організаційних форм виробничого управління (від великих бюрократичних структур до невеликих ієрархічних спілок).

Отже, епіцентр стратегічного орієнтиру діяльності товаровиробників на національному та світовому ринках поступово переміщується 3 сфери економії витрат окремого товаровиробника в економію суспільних витрат за рахунок підвищення ефективності управління інтегрованими виробничими системами. Іншими словами, перехід до постіндустріального типу розвитку обумовлений змінами, що відбуваються як у соціально-культурній, так i техніко-технологічній сферах, які здійснюють синергетичний вплив на стратегічні орієнтири та перспективи розвитку товаровиробників за рахунок [3]:

1) сфери економіки, де відбувається перехід до наукоємного та нематеріального виробництва;

2) сфери зайнятості, що характеризується домінуванням класу спеціалістів та техніків, які $\epsilon$ основою для формування інтелектуально-креативної еліти;

3) «осьового принципу», згідно з яким джерелом інновацій є теоретичні знання. Відповідно, наука стає безпосередньою виробничою силою, а наукова діяльність - провідною сферою діяльності. Результатом перетворення науки в безпосередню виробничу силу стає збільшення питомої ваги знань у виготовлених товарах, що призводить до зниження ресурсоємності виробництва; підвищення конкурентоспроможності продукції та отримання високого рангу у економічній стратифікаційній системі.

4) майбутньої орієнтації, що базується на технічних та технологічних видах діяльності;

5) створенні нових «інтелектуальних технологій».

Ще одним 3 чинників, що впливає на стратегічні орієнтири та перспективи розвитку національного товаровиробника $є$ інформаційний тиск на виробництво, що обумовлений наступними факторами:

По-перше, інформація, поряд із знаннями стає економічним фактором виробництва [4, с.180; 5, с. 3-4 ]: Це відбувається за рахунок того, що: 
- будь яка інформація, незважаючи на іiі властивість безмежно розповсюджуватись - $\epsilon$ унікальною для кожного окремого економічного агента;

- цінність інформації обумовлена іiі необхідністю для кожного окремого підприємства, що на відміну від інших факторів виробництва - є суб'єктивною характеристикою;

- інформація може не тільки використовуватись у необмеженій кількості відтворювальних циклів в процесі виробництва та має довгостроковий характер, а й здатна до самозростання;

- інформація, як і будь-який виробничий ресурс є об'єктом власності;

- інформація стає доступною широкому колу з моменту ії відтворення;

- засвоєння інформації одним економічним агентом не передбачає іiі відчуження від іншого;

- вартість інформації з часом зменшується;

- незважаючи на те, що вартість переносу інформації значно вище за витрати тиражування, інформація не має властивості безмежного самозростання;

- витрати на відтворення з кожним новим етапом технічного прогресу прагнуть до нуля.

По-друге, зростає кількість спеціалістів, які займаються ІКТ та виробництвом інформаційних продуктів і послуг, що збільшує частку інформаційних продуктів та послуг у виготовленому товарі. Внаслідок появи інформаційних мереж створюється єдиний інформаційний простір, що задовольняє потреби в інформаційних продуктах та послугах. За рахунок автоматизації виробництва посилюється взаємозв'язок науки з виробничими процесами. В результаті відбувається формування ринку інформації, базою якого стає використання інформаційних важелів для прийняття економічних рішень та способів впливу на економічних контрагентів. Як наслідок, створюється глобальний інформаційний простір, що забезпечує ефективну інформаційну взаємодію людей, доступ до світових інформаційних ресурсів та задоволення потреб в інформаційних продуктах і послугах.

Отже, перетворення інформації в найважливіший ресурс розвитку сучасної економіки, усвідомлення інформації як товару та як інструмента влади, безперервне зростання обсягів інформації - обумовлюють необхідність застосування нових інформаційних технологій, що сприяють процесам трансформації економічних агентів у світові лідери.

В якості прикладу можна привести американську транснаціональну нафтову компанію Exxon Mobil corporation (NYSE:XOM). Ця компанія за рахунок модернізації та впровадження нових комп'ютерних технологій, що використовуються для адаптації обсягів виробництва на нафтових заводах та розкладу рейсів танкерів до змін попиту на світовому ринку, змогла значно 
збільшити свої ринкові позиції за останні десять років. Сьогодні, компанія займає другу сходинку у рейтингу британської газети Financial Times (FT500). IIÏ капіталізація, незважаючи на кризу, вже другий рік поспіль залишається незмінною і становить 403,7 млрд. доларів [6].

Таким чином, розвиток ІКТ призводить до необхідності адаптації суб'єктів господарської діяльності до динамічних змін у інформаційному середовищі, що формується під впливом двох протилежно спрямованих тенденцій: 3 одного боку, економічні агенти прагнуть до створення інформаційних бар'єрів задля забезпечення комерційної безпеки та конкурентних переваг. А з іншого, підприємства прагнуть до інтеграції за рахунок розширення доступу до інформаційних ресурсів з метою підвищення свого рейтингу на всіх типах ринків. У сукупності означені чинники сприяють створенню інформаційно-мережевої інфраструктури, за рахунок якої забезпечується ефективна праця товаровиробників, оптимізуються виробничі процеси через використання віртуального простору, збільшуються прибутки та підвищується статус підприємств на ринку.

Підкреслимо, що роль інформації у стратегічному розвитку високотехнологічних підприємств добре простежується у теорії «інформаційної глобалізації» (більш відомої як «теорії золотого мільярда»), причинами появи якої стали [ 7, с.37-45]

- тісний зв'язок між науковими та технічними розробками у XX столітті, внаслідок чого виробництво стало більш динамічним;

- впровадження ІКТ в усі сфери життя;

- поява нових інформаційно-комунікаційних мереж надала можливості кожному суб'єкту господарської діяльності для доступу до інформаційних ресурсів, що сприяє об'єднанню знань;

- інформація та знання за рахунок швидкого зростання стали джерелом появи нових робочих місць;

- розвиток ІКТ надав можливості для появи гнучких мережевих типів організації підприємств, що мають можливість для швидкого впровадження інноваційних рішень.

Як результат, виникає новий феномен організації бізнесу та нова парадигма в контексті розвитку теорії фірм - мережеві підприємства, які у західних дослідженнях отримали назву «підприємства 3 модульною структурою», або «динамічні мережеві підприємства», що здатні до генерації нових знань та швидких змін цілей під впливом технологічних та культурних змін.

На відміну від традиційної організації бізнесу, в основі якого лежить значні обсяги фізичного капіталу, а досягнення лідерських позицій на ринку відбувається за рахунок удосконалення ланцюга «постачальник - споживач», мережеве підприємство має відносно невеликий капітал, але володіє торговою 
маркою (брендом). В цьому випадку, зовнішні структури утворюють мережу навколо таких підприємств та надають йому різні послуги (як то: обробка інформації, облік, підбір персоналу тощо).

Перехід до модульної структури, на підприємствах призводить до появи вільних ресурсів, що спрямовуються на розробку брендів, залучення споживачів, логістику та інші процеси, що забезпечують лідерство підприємства в галузі. Отже, базою розвитку мережевих підприємств стає господарська діяльність, що базується на використанні Інтернет технологій та підвищенні ролі між фірмової кооперації.

У загальному вигляді, мережа являє собою відкриту структуру 3 безмежною кількістю вузлів, що підтримують комунікаційні коди означеної мережі. Основою для розвитку модульної структури підприємства $€$ певний набір самостійних мережевих агентів (виробничих, транспортних, консалтингових, дистриб'юторських тощо), які $\epsilon$, або були партнерами та діють в межах цієї мережі з метою створення загального ланцюга цінності. Мережева форма організації виробничого процесу має можливість до швидких змін в товарах та послугах за рахунок безпосередньої близькості партнерів до кінцевих споживачів. Крім того, будь-які нововведення, що здійснюють партнери промислової мережі, сприяють розвитку адаптаційних процесів та надають можливості для безперервної освіти всередині усієї мережі. Це призводить до накопичення ноу-хау, що стосуються як виробничих, так і організаційних процесів роботи мереж як всередині окремого підприємства, так і в межах усієї мережі та знаходить своє відображення в комбінації операційних, інвестиційних та адаптаційних процесів створення нової вартості.

В основу організації модульної структури підприємства покладено [8]:

- наявність загальної мети, що досягається за рахунок мережевої взаємодії партнерів та забезпечує стійкість такого партнерства;

- незалежність партнерів, які мають можливість для реалізації власних задач та отримують додаткову вигоду від інтеграційних процесів взаємодії;

- взаємозалежність учасників мережі;

- множинність лідерів (еліти), які дозволяють забезпечити стійкість i еластичність мережі за рахунок унікальності знань кожного 3 партнерів;

- багаторівневість інтегрованих рівнів модульної системи, що надає можливості безпосередньої взаємодії з будь-яким партнером цієї мережі.

Найкращим прикладом модульної організації виробництва $\epsilon$ австралійська фірма - TCG Group (Technical and Computer Graphics Group), яка за рахунок створення мережевої форми організації бізнесу не тільки стала 
найбільшим приватним бізнесом комп'ютерних послуг в Австралії, а й моделлю самоврядних організацій. Основним організаційним досягнення означеної компанії є здатність до інновацій, що надає можливості для отримання нових знань в результаті будь-якого комерційного проекту. Підприємства, що входять до складу TCG Group являють собою, так названу «кліткову структуру», кожне 3 яких може існувати самостійно, але за рахунок взаємодії з іншими підприємствами, отримує синергетичний ефект від накопичення знань, що передбачають загальні операційні та адаптаційні процеси, які забезпечують зв'язки між зовнішніми та внутрішніми партнерами. За умов організації модульної структури, зовнішні партнери забезпечують фінансовими та технічними ресурсами, необхідними для здійснення проекту, а внутрішні - надають інформацію, за рахунок якої розподіляються знання всередині організації.

В Україні, прикладом створення мережевої організації виробництва виступають кластери, що об'єднують ресурси та ключові компетенції різних організацій, що входять до їх складу. Зазвичай виділяють три види мережевої організації бізнесу:

1) Внутрішні мережі, що передбачають роботу окремих підрозділів, засновану на ринкових принципах. де кожний підрозділ має можливість отримувати додаткові закази ззовні.

2) Стабільні мережі, активи яких належать декільком спеціалізованим фірмам, що $є$ або постачальниками ресурсів, або дистриб'юторами продукції. В якості прикладу стабільних мереж виступають галузі, що потребують значних капітальних інвестицій, як то: машинобудування, металургійна та хімічна промисловість.

3) Динамічні мережі, що створюються для одноразового або короткострокового проекту з мінімальними витратами та втратами часу (як то: легка промисловість, біотехнології, комп'ютерний бізнес).

Основними перевагами модульної організації бізнесу стають:

- необмежена кількість учасників бізнесу (мінімальна кількість - три);

- економія витрат на переміщеннях за рахунок створення гнучких форм співробітництва;

- колективне формування інформаційних ресурсів;

- зниження витрат на внутрішне інформаційне середовище;

- внутрішня координація роботи, що забезпечує творчу взаємодію.

Підкреслимо, що в умовах постійних змін, які відбуваються у сучасній економіці, виробнича та комерційна діяльність підприємств все більше ускладнюється. Це вимагає від менеджерів пошуку нових методів адаптації, що відбуваються під впливом двох основних факторів: фактору часу та фактору розширення простору. Підвищення оперативності дій (фактор часу) потребує нового підходу щодо пошуку нових методів управління 
виробництвом, а бажання отримання в високих позицій у певній галузі на всіх типах ринків вимагає від товаровиробників розширення ринків збуту (фактор розширення простору).

Якщо в індустріальну епоху, основними способами координації діяльності підприємства було вертикальне управління (ієрархія), то в сучасний період становлення постіндустріального суспільства все більшого розповсюдження набуває гібридний варіант - кластерно-мережевий принцип організації підприємств, який відображає зв'язок між елементами внутрішнього та зовнішнього середовища підприємства.

Зазвичай, кластер, розглядається як група географічно взаємопов'язаних підприємств та організацій, які діють у певній галузі. Це певний різновид мереж, в основі організації яких лежать п'ять основних умов, що отримали назву - «Концепція «5-І»»: ініціатива; інформація, інвестиції, інтеграція та інтерес [9, с. 258-269]. В основі модульного принципу організації кластеру лежить спосіб регулювання взаємозалежності учасників єдиного технологічного процесу для сумісної реалізації підприємницьких проектів, що заснований на ефективному використанні ресурсів. Основними характеристиками таких мереж виступають: єдина ціль, чіткість внутрішньої структури, високий ступінь взаємозв'язку між структурними елементами та зовнішнім середовищем.

Формування кластерно-мережевих організацій відбувається під впливом двох основних факторів, що умовно визначають як кластероутворюючі та кластеропідтримуючі фактори. До кластероутворюючих факторів належать:

- концентрація, як синергія основних умов для забезпечення лідерства;

- комунікація, що дозволяє здійснювати регулярний обмін інформацією між учасниками кластерної мережі;

- конкуренція, яка за рахунок об'єднання підприємств у кластери, є стимулом для підвищення якості продукції та розширення ринків збуту. В основі кластеропідптимуючих факторів лежать:

- спеціалізація, яка за рахунок уніфікації виробництва призводить до підвищення якості продукції і збільшення іії конкурентоспроможності;

- співробітництво, що передбачає спільні зусилля підприємств в процесі конкурентної боротьби;

- синергія, що передбачає системний (емерджентний) ефект від спеціалізації та співробітництва.

Результатом кластерно-мережевої системи організації виробництва стає синергетичний ефект взаємодії об'єднаного економічного агента по зрівнянню з окремими суб'єктами господарювання. Цей ефект досягається за рахунок зниження транзакційних витрат, зменшення внутрішніх та зовнішніх ризиків, підвищення конкурентоспроможності та інноваційності продукції, i 
як наслідок покращення економічного статусу такого економічного агента у глобальному економічному просторі.

Світовий досвід доводить, що в основі діяльності світових підприємствлідерів сьогодні лежить саме кластерно-мережевий принцип організації виробництва. Про це свідчить розвиток світових високотехнологічних комплексів, що спирається на модульну організацію інноваційного типу.

Так, згідно 3 даними Міжнародного центру наукової та технічної інформації за 2013 рік найбільша кількість кластерів спостерігається у США (380), Італії (206) та Великобританії (168) [10]. За рахунок розвитку деревообробних кластерів та кластерів, що функціонують на телекомунікаційному ринку, Фінляндія забезпечує $10 \%$ світового експорту деревообробної продукції, 25\% - паперу та 40\% мобільних телефонів. На основі кластерно-мережевої організації функціонують:

- у Швейцарії - кластери, що працюють у галузі електронних технологій, зв'язку та інформації, машинобудування та електроніки;

- у Фінляндії - кластери, що працюють у галузі електронних технологій, зв'язку та інформації, комунікації та транспорту, будівництві, легкій промисловості та лісогосподарському комплексі;

- у Німеччині - хімічні кластери, біотехнологічні та машинобудівні промислові кластери;

- у Франції кластери харчової промисловості, фармацевтичні та косметичні.

Результатами такої кластерізації стають:

1. збільшення обсягів продажу на всіх типах ринків (локальному та міжнародному);

2. надання можливості підприємствам розширити виробничий потенціал на існуючих та нових ринках;

3. збільшення прямих іноземних інвестицій;

4. залучення нових форм співпраці 3 іноземними партнерами, що базуються на використанні інтелектуально-креативного потенціалу.

У сукупності все це призводить до максимізації прибутків підприємств в умовах мінімізації витрат та надає їм можливості отримати статус лідера як на національному, так і на світовому ринках.

3 метою розвитку кластерно-мережевої організації бізнесу, урядами європейських держав створено різні цільові програми. Так, наприклад в Німеччині, для розвитку сфери біотехнологій, урядом створено низку цільових програм, таких як Bio Regio (створення «біорегіонів»), Bio Profile (медичні біотехнологіi), Bio Chance PLUS (інновації в біотехнологіях), «KMU - innovative: Biotechnologie - Bio Chance» (для малого і середнього бізнесу), «GO - BIO» (по створенню нової продукції для світових ринків). В основу кластерної політики Фінляндії, покладено програму створення експертних 
центрів (OSKE), що спеціалізуються на розвитку високотехнологічного виробництва, а саме: біотехнологій; цифрового бізнесу; енергетики; інтелектуальних технологій; нанотехнологій тощо.

Щодо України, зазначимо, що сьогодні, питанням формування кластерно-мережевої організації виробництва приділяється багато уваги. На сьогодні в Україні створено правове поле для створення кластерно-мережевих моделей. Зокрема, ця сфера Програмою діяльності Кабінету Міністрів України «Український прорив: для людей, а не політиків»; «Державною програмою активізації розвитку економіки на 2013-2014 роки»; Розпорядженням Кабінету Міністрів України від 28 серпня 2013 р. року «Про схвалення Концепції Загальнодержавної програми розвитку малого $\mathrm{i}$ середнього підприємництва на 2014-2024 роки» тощо.

3 метою формування модульної структури організації бізнесу, у вересні 2008 року була розроблена «Концепція створення кластерів», що надала можливості для створення низки кластерів, що демонструють ефективність своєї роботи як на національному, так і на світовому ринках [11], як то: інноваційний кластер «Впровадження», що діє у у Рівненській області; «Інноваційно-технологічний кластер малого та середнього машинобудівного бізнесу» у Запорізькій області, інноваційний технологічний кластер «Транспортне машинобудування та технології перевезень» у Дніпропетровську; Мелітопільский машинобудівний кластер "АгроБУМ»; інноваційно-інвестиційний кластер у м. Тернопіль; національний інноваційний кластер «Нові технології природокористування» на Донеччині; національні інноваційні кластери «Енергетика сталого розвитку» та «Технології інноваційного суспільства» у м. Києві (Політехніка) тощо.

Висновки. Результати проведеного дослідження надають можливість зробити наступні висновки: реалізація нової парадигми розвитку сучасних підприємств обумовлює потребу визначення впливу екзогенних зовнішніх факторів на стратегію діяльності вітчизняних підприємств. Отже, у результаті теоретичного узагальнення були виявлені пріоритетні фактори, що здійснюють найбільший вплив на формування стратегії розвитку вітчизняного промислового підприємства, серед яких особливої уваги потребують: розвиток сучасної інноваційної економіки, що базується на знаннях; посилення інформаційного впливу на виробництво; кластерно-мережевий характер організації та управління виробництвом.

На основі аналізу екзогенних факторів впливу на стратегію розвитку вітчизняних підприємств визначено, що сьогодні найбільш перспективними 3 точки зору отримання високих позицій у світових рейтингах мають підприємства, що застосовують кластерно-мережевий принцип організації виробництва. Набуло подальшого розвитку еволюційна концепція формування імперативів розвитку підприємств шляхом урахування фактору 
часу та фактору розширення простору, що надають можливість для швидкої адаптації до умов, що постійно змінюються.

Отже перспективою подальшого дослідження у визначеному напрямку повинно стати поглиблене дослідження пріоритетних напрямів та перспектив розвитку вітчизняних промислових підприємств.

\section{Література:}

1. Белл Д. Социальные рамки информационного общества [Текст] / Д. Белл. - М.: Экономика, 2004. - 308 с.

2. Белл Д. Грядущее постиндустриальное общество: Опыт социального прогнозирования. [Текст] / Д. Белл. Перевод В.П. Иноземцева. М.: Academia. 1999, 949 с.

3. Шевчук О.А. Еліта як домінанта розвитку людського капіталу: Монографія $\mathrm{MOH}$ України, НТУУ «КПІ» [Текст] / О.А. Шевчук / - К. ТОВ «Інтерсервіс»: 2012. - 249 с.

4. Иноземцев В. Парадоксы постиндустриальной экономики (инвестирование, производительность и хозяйственный рост в 90-е годы) [Текст] / В. Иноземцев // Мировая экономика и международные отношения: 2000 - №3 - С. 3-11.

5. Смирнов А.И. Информационная глобализация и Россия: вызовы и возможности. [Текст] / А.И.Смирнов - М.: Издательский дом «Парад», 2005.,-392 с.

6. Miles R., Snow C., Fit, Failure, and the Hall of Fame: How Companies Succeed or Fail. / R. Miles, C. Snow / Free press, 1994 p. 218

7. Иноземцев В. За пределами экономического общества: Постиндустр. теории и постэкон. тенденции в соврем. мире [Текст] / В. Л. Иноземцев. — М.: Academia : Наука, 1998. — $639 \mathrm{c}$.

8. Асаул А.Н. Организация предпринимательской деятельности: учебник [Текст] / А.Н. Асаул- СПб.: АНО ИПЭВ, 2009. 336с.

9. Войнаренко М.П. Кластери в інституційній економіці : монографія / [Текст] /М.П. Войнаренко. - Хмельницький : ХНУ, ТОВ "Тріада-М", 2011. - 502 с. 85 УДК 338.242

10. Инновационно-технологические кластеры стран - членов МЦНТИ (Информационный материал) [Електронный Ресурс] /Международный центр научной и технической информации - февраль 2013, Режим доступа: http://www.icsti.su/uploaded/201304/cluster.pdf

11. Пріоритети інвестиційної політики в контексті модернізації економіки України. Аналітична доповідь. [Електронный Ресурс] / За редакцією к. е. н., с. н. с., заслуженого економіста України Я. А. Жаліла / Національний інститут стратегічних досліджень , К.:, 2013 Режим доступу : http://www.niss.gov.ua/content/articles/files/Invest_polit.inddc9ae5.pdf

\section{References:}

1. Bell D. Sotsialnyie ramki informatsionnogo obschestva [Tekst] / D. Bell. - M.: Ekonomika, 2004. $-308 \mathrm{~s}$.

2. Bell D. Gryaduschee postindustrialnoe obschestvo: Opyit sotsialnogo prognozirovaniya. [Tekst] / D. Bell. Perevod V.P. Inozemtseva. M.: Academia. 1999, 949 s.

3. Shevchuk O.A. ElIta yak domInanta rozvitku lyudskogo kapItalu: Monograflya MON UkraYini, NTUU «KPI» [Tekst] / O.A. Shevchuk / - K. TOV «InterservIs»: 2012. - 249 s. 
4. Inozemtsev V. Paradoksyi postindustrialnoy ekonomiki (investirovanie, proizvoditelnost i hozyaystvennyiy rost v 90-e godyi) [Tekst] / V. Inozemtsev // Mirovaya ekonomika i mezhdunarodnyie otnosheniya: 2000 - \#3 - S. 3-11.

5. Smirnov A.I. Informatsionnaya globalizatsiya i Rossiya: vyizovyi i vozmozhnosti. [Tekst] / A.I.Smirnov - M.: Izdatelskiy dom «Parad», 2005.,-392 s.

6. Miles R., Snow C., Fit, Failure, and the Hall of Fame: How Companies Succeed or Fail. / R. Miles, C. Snow / Free press, 1994 r. 218 p.

7. Inozemtsev V. Za predelami ekonomicheskogo obschestva: Postindustr. teorii i postekon. tendentsii v sovrem. mire [Tekst] / V. L. Inozemtsev. — M.: Academia : Nauka, 1998. — 639 s.

8. Asaul A.N. Organizatsiya predprinimatelskoy deyatelnosti: uchebnik [Tekst] / A.N. AsaulSPb.: ANO IPEV, 2009. 336s.

9. Voynarenko M.P. Klasteri v InstitutsIynIy ekonomItsI : monograflya / [Tekst] /M.P. Voynarenko. - Hmelnitskiy : HNU, TOV "TrIada-M", 2011. - 502 s. 85 UDK 338.242

10. Innovatsionno-tehnologicheskie klasteryi stran - chlenov MTsNTI (Informatsionnyiy material) [Elektronnyiy Resurs] /Mezhdunarodnyiy tsentr nauchnoy i tehnicheskoy informatsii - fevral 2013, Rezhim dostupa: http://www.icsti.su/uploaded/201304/cluster.pdf

11. Prioriteti InvestitsIynoYi polItiki $\mathrm{v}$ kontekstI modernIzatsIYi ekonomIki UkraYini. AnalItichna dopovId. [Elektronnyiy Resurs] / Za redaktsIEyu k. e. n., s. n. s., zasluzhenogo ekonomIsta UkraYini Ya. A. ZhalIla / NatsIonalniy Institut strategIchnih dosIIdzhen , K.:, 2013 Rezhim dostupu : http://www.niss.gov.ua/content/articles/files/Invest_polit.inddc9ae5.pdf 